\title{
Measuring synergy within a Triple Helix innovation system using game theory: cases of some developed and emerging countries
}

Correspondence: eustache. megnigbeto@uantwerpen.be; eustachem@gmail.com ${ }^{1}$ University of Antwerp, Faculty of Social Sciences, B-2000 Antwerp, Belgium

${ }^{2}$ Bureau d'études et de recherches en science de l'information, 09 BP 477 Saint Michel, Cotonou, Republic of Benin

\begin{abstract}
Synergy within a Triple Helix innovation system has been measured in relevant literature using mutual information and transmission power, all based on Shannon's information theory. However, as a complex system, Triple Helix relationships may also be analysed with various techniques and tools from other disciplines among which game theory. Thus, the synergy may be measured with indicators like the core, the Shapley value and the nucleolus. The core measures the extent of the synergy, the Shapley value indicates an actor's strength to lead to and create synergy and the nucleolus determines an actor's strength to maintain synergy. The Triple Helix innovation systems of eight countries among which four developed — USA, UK, Germany and France — and four emerging — Russia, India, Brazil and China - were analysed based on their scientific output using game theory. It appears that the biggest Triple Helix science producer has more power to lead to and create synergy; government shows solidarity to maintain synergy within the innovation system. The level of synergy is higher in developing countries (led by France, 1.7-2\%) than in emerging ones (led by Brazil, less than or equal to 1\%), operating a division of selected countries according to their level of development. The study shows that state intervention in the economy influences the position of the core on a ternary diagram.
\end{abstract}

Keywords: Triple Helix, Game theory, Innovation, Innovation system, Core, Shapley value, Nucleolus

\section{摘 要}

在三螺旋创新体系内的协同作用已经在相关文献中利用互信息和传输功率被测 量,所有这些测量都基于Shannon(香农)的信息理论。然而,作为一个复杂的体 系，三螺旋关系也可以利用其他学科的技术和工具进行分析，其中包括博弯论。因 此,协同作用可以用诸如核心、夏普利值(Shapley value)和核仁指标来测量。核心 测量协同作用的程度,夏普利值体现一个主体导致并产生协同作用的力量,核仁则 决定了主体保持协同作用的力量。利用博弯论,基于其科学输出,我们对八个国家 的三螺旋创新体系进行了分析,包括四个发达国家 - - 美国、英国、德国和法 国，以及四个新兴国家 - - - 俄罗斯、印度、巴西和中国。似乎最大的三螺旋科 学生产者有更多的力量来引起和创造协同作用; 在创新体系内政府表现出团结 一致以保持协同效应。发展中国家(以法国为首, 1.7-2\%)的协同作用水平高于新兴 国家(以巴西为首,小于或等于1\%),根据其发展水平对选定国家进行划分。此研究 表明,国家对经济的干预会影响核心在三元图上的位置。

关键词:三螺旋, 博弯论, 创新, 创新体系, 核心, 夏普利值, 核仁 


\section{Résumé}

La synergie dans un système d'innovation de la Triple Hélice a été mesurée dans la littérature appropriée avec l'information mutuelle et la puissance de transmission, toutes basées sur la théorie de l'information de Shannon. Cependant, en tant que système complexe, un système d'innovation de la Triple Hélice peut être également analysé avec divers techniques et outils empruntés à d'autres disciplines dont la théorie des jeux. Alors, la synergie peut être mesurée avec les indicateurs comme le noyau, la valeur de Shapley et le nucleolus. Le noyau mesure le niveau de synergie, la valeur de Shapley indique le pouvoir d'un acteur à conduire à la synergie ou en créer et le nucléolus détermine le pouvoir d'un acteur à maintenir la synergie. Le système d'innovation de la Triple Hélice de huit pays dont quatre développés - USA, Royaume Uni, Allemagne et France - et quatre émergents - Russie, Inde, Brésil et Chine - a été analysé sur la base des publications scientifiques en utilisant la théorie des jeux. II apparaît que le plus grand producteur de science de la Triple Hélice a le plus de pouvoir pour conduire à la synergie et en créer, et que le gouvernement est plus solidaire en vue de maintenir la synergie dans un système d'innovation. Le niveau de synergie est plus élevé dans les pays développés (avec en tête la France, 1,7-2\%) que dans les pays émergents (avec en tête le Brésil, moins de 1\%), opérant ainsi une division des pays suivant leur niveau de développement. Cette étude montre que la politique d'intervention de l'Etat dans l'économie influence la position du noyau sur un diagramme ternaire.

Mots-clés: Triple Hélice, Théorie des jeux, Innovation, Système d'innovation, Noyaux, Valeur de Shapley, Nucleolus

\section{Resumo}

Sinergia dentro de um sistema de inovação Triple Helix foi medido na literatura relevante usando informação mútua e poder de transmissão, todos baseados na teoria da informação de Shannon. No entanto, como um sistema complexo, as relações Triple Helix também podem ser analisadas com várias técnicas e ferramentas de outras disciplinas, entre as quais a teoria dos jogos. Assim, a sinergia pode ser medida com indicadores como o núcleo, o valor de Shapley e o nucléolo. O núcleo mede a extensão da sinergia, o valor de Shapley indica a força de um ator para conduzi-la e criar sinergia e o nucléolo determina a força de um ator para mantê-la. Os sistemas de inovação Triple Helix de oito países, dos quais quatro se desenvolveram - EUA, Reino Unido, Alemanha e França - e quatro emergentes - Rússia, Índia, Brasil e China - foram analisados com base em sua produção científica usando a teoria dos jogos. Parece que o maior produtor de ciência da Triple Helix tem mais poder para liderar e criar sinergia; o governo mostra solidariedade para manter a sinergia dentro do sistema de inovação. O nível de sinergia é maior nos países em desenvolvimento (liderados pela França, 1,7$2 \%$ ) do que nos emergentes (liderados pelo Brasil, iguais ou inferiores a 1\%), operando uma divisão de países selecionados de acordo com seu nível de desenvolvimento. O estudo mostra que a intervenção estatal na economia influencia a posição do núcleo em um diagrama ternário.

Palavras-chave: Triple Helix, Teoria do jogo, Inovação, Sistema de inovação, Testemunho, Valor Shapley, Nucléolo 


\begin{abstract}
Аннотация
Синергия в рамках Инновационной системы Тройной спирали измерена в соответствующей литературе с применением информационных и инструментальных методов, основываясь на Теории информации Шэннона. Тем не менее, в более сложных системах, взаимодействия в рамках тройной спирали могут быть также проанализированы при помощи различных техник и инструментов, позаимствованных в других дисциплинах, среди которых Теория игр. Так, синергию можно оценить через такие индикаторы как ядро, значения и нуклеос Шепли. При измерении зависимости между ядром и синергией, значение Шепли указывает на способность актора к созданию и управлению синергией. Инновационные системы Тройной спирали в восьми странах, из которых четыре - развитые (США, Великобритания, Германия, Франция), а другие четыре развивающиеся (Россия, Индия, Бразилия и Китай), были проанализированы в контексте создания ими научных продуктов при помощи теории игр. Получили, что наиболее активный производитель научного продукта в Тройной спирали обладает большей способностью к управлению и созданию синергии; государство проявляет аналогичные способности в сохранении синергии с инновационной системе. Уровень синергии является более высоким в развитых странах (лидером является Франция, 1,7-2\%) в сравнении с развивающимися странами (лидером является Бразилия, около 1\%), остальные страны распределены в соответствии с их уровнем развития. Исследование показывает, что вовлечение государства в экономику влияет на положение ядра в диаграмме состояния тройной системы.
\end{abstract}

\title{
Resumen
}

La sinergia dentro de un sistema de innovación Triple Helix ha sido cuantificada usando la teoría de la información de Shannon con medidas de información mutua y poder de transmisión. Sin embargo, las relaciones de Triple Helix también pueden analizarse con técnicas y herramientas de otras disciplinas, incluyendo teoría de juegos. Por lo tanto, la sinergia se puede medir con indicadores como núcleo que mide el alcance de la sinergia, el valor de Shapley que indica la fuerza de un actor para conducir y crear sinergia, y el nucléolo que determina la fuerza de un actor para mantener la sinergia. Usando teoría de juegos, aquí se analizan las funciones de producción científica del sistema de innovación de ocho países, cuatro de ellos desarrollados (EE. UU., Reino Unido, Alemania y Francia) y cuatro emergentes (Rusia, India, Brasil y China). Parece que el mayor productor de ciencia tiene más poder para conducir y crear sinergia; esto incluye un alineamiento del gobierno con este propósito. El nivel de sinergia es mayor en los países en desarrollo (liderados por Francia, 1.7-2\%) que en los emergentes (liderado por Brasil, menor o igual al 1\%). El estudio muestra que la intervención estatal en la economía influye en la posición del núcleo en un diagrama ternario.

Palabras Clave: Triple Hélice, Teoría de juegos, Innovación, Sistema de innovación, Núcleo, Valor Shapley, Nucléolo 


\section{Multilingual abstract}

Please see Additional file 1 for translation of the abstract into Arabic.

\section{Introduction}

Innovation is a process that starts with basis research and ends with the commercialisation of knowledge (Godin 2005, 2006, 2014). Measuring innovation has been a concern in research and innovation circles since decades. For example, initiatives have been taken at international level: (i) the Frascati Manual (OECD 2015) firstly adopted in 1963 sets forth the methodology for selecting statistics about research and development, (ii) the Oslo Manual (OECD and EUROSTAT 2005) proposed guidelines for collecting and interpreting technological innovation data and (iii) OECD (2010) published 'Measuring innovation: a new perspective' where details were given on the content of the concept and some indicators that could capture it. Despite the existence of these publications, the indicators used for the assessment of innovation activities are not the same from one country or institution to another, from one institution or even from one publication of the same institution to another; the European innovation scoreboard for innovation (European Commission 2010, 2014) over various years constitutes an illustration. Currently, there is no internationally accepted indicator to capture the concept (Mêgnigbêto 2016a).

The Triple Helix of university-industry-government relationships (Etzkowitz and Leydesdorff 1995, 2000; Leydesdorff and Etzkowitz 1996, 2001) is a variant of the nonlinear model of innovation (Etzkowitz et al. 2000; Leydesdorff 2012; Meyer et al. 2014). It theorises that innovation results from the synergy between the three main actors (university, industry and government). According to François (2004), synergy is the fusion between different aims and resources to create more between the interacting parties than they had prior to the interactions; an object shows synergy when, examining one of various of its parts (or even each or everyone of them) separately, it is impossible to explain or predict the whole's behaviour. So, measuring the synergy within a Triple Helix innovation system equates measuring innovation within that innovation system. Can synergy be measured within an innovation system? Leydesdorff and Park (2014) responded in the affirmative. Leydesdorff (2003) stated that the interacting fluxes generate probabilistic entropy and may be measured as an indicator of entropy; in other words, research collaboration relations between any couple of actors or all the three actors may be measured as entropy using Shannon's (1948) information theory. Leydesdorff (2003) then introduced the mutual information as an indicator of synergy within the Triple Helix innovation system. But, Shannon's (1948) mutual information was defined for two variables and is always positive or null; with three and more variables, the mutual information is no longer a Shannon-type information because it may be negative. Mêgnigbêto (2014a, 2016a) warmed that the mutual information could not serve for comparing a same system over time or two different systems, because its variability depends on variables in presence; then, he proposed its normalisation under the name of transmission power that indicates the part of sharable information really shared within an innovation system. For example in 2001, the US mutual information was -74.417 millibits and the one of India was -78.106 millibits (cf. Mêgnigbêto 2014a); but that year, the US system might produce up to - 248.88 millibits and the Indian one up to -440 millibits; so the mutual information represents $29.9 \%$ of the total capacity of information production of the US system and $16.9 \%$ of the Indian one; these percentages are the transmission power. 
The mutual information and the transmission power have been used to study different innovation system throughout the world, for example the OECD countries (Mêgnigbêto 2015a, 2016b; Choi et al. 2015), South Korea (Park and Leydesdorff 2010; Khan and Park 2011; Kwon 2011; Kwon et al. 2012; Mêgnigbêto 2015b), USA, UK, France, Germany, Brazil, China, India, Russia, South Korea, Japan (Leydesdorff 2003; Leydesdorff and Sun 2009; Ye et al. 2013; Mêgnigbêto 2014a, 2015a, b, 2016a, b), West African region and countries (Mêgnigbêto 2013, 2014b, c, 2015b, c) China (Leydesdorff and Zhou 2013), Saudi Arabia (Shin et al. 2012), Russia (Ekaterina 2012; Leydesdorff et al. 2015) or Norway (Ivanova et al. 2014). The main of these studied may be summarised as follows: (i) the mutual information is negative, generally, meaning existence of synergy within the considered innovation systems, even though the extent varies from one country or region to another; the transmission power is weak, generally, meaning that a low part of information was shared among innovation actors.

While studying the USA, UK, Germany, France, Russia, India, Brazil, China, South Korea and West Africa with mutual information, Mêgnigbêto (2014a) established that the synergy operates more in South Korea, India, France, USA, UK and Germany than elsewhere (probably, because the South Korean data source-Internet-was not the same as that of the other countries-Web of Science); China is at the rear coming after Russia, Brazil and West Africa in this order. Regarding the transmission power, USA devoted the largest part of its information capacity production to the synergy between the Triple Helix spheres followed by South Korea, UK, Germany and France. West Africa and China have the lowest transmission power values. Except South Korea that positions among Western countries, the transmission power operates a division of the selected countries into two parts: the developed countries led by USA, on one hand, and the developing ones led by India, on the other (see Mêgnigbêto 2014a, 2016a).

The mutual information was criticised; according to Krippendorff (2009a, b), this indicator fails to measure the interaction information it is intended to in more than two dimensions, e.g. with more than two variables. Innovation systems are complex systems (Katz 2006, 2016); Leydesdorff (2003) asserted that the Triple Helix of university-industry-government relationships constitute a complex system that, therefore, could be analysed with techniques and tools from cybernetics, information theory, game theory, decision theory, topology or mathematics of relations or factorial analysis (von Bertalanffy 1973). Recently, Mêgnigbêto (Mêgnigbêto 2017; 2018) proved that the Triple Helix innovation system with publication as unit of analysis is a cooperative game with transferable utility; then, the core, the Shapley value and the nucleolus were proposed as indicators of synergy. The application of these indicators to the West African and the South Korean Triple Helix games (Mêgnigbêto 2018) led to the following main findings: (i) university, the biggest Triple Helix producer, has more power to lead to and create synergy, followed by government in second position and industry in third position; (ii) together, university and government have the largest interest in the Triple Helix game; (iii) the nucleolus value is less generous towards government when compared with the Shapley value, meaning that government and its partners maintain the synergy within the Triple Helix system.

This study seeks to determine the profile of selected countries regarding the core, the Shapley value and the nucleolus. We formulate the following research questions: (i) 
What are the rules of the Triple Helix game of the selected countries? (ii) How do the selected countries perform with regard to game theory indicators? (iii) How does selected countries profile compare with mutual information or transmission power? The paper intends to answer these research questions. It is structured as follows: in the second (next) section, we explain the rules of the Triple Helix game; the third section gives a background on the core, the Shapley value and the nucleolus; the fourth deals with research data collection, and the fifth presents the analyses; the sixth section discusses the results; and the last section summarises the main findings and concludes.

\section{Methods and data}

In a Triple Helix innovation system, actors interact mainly by means of collaboration. By doing so, they pursue the goal of maximising the number of papers they publish individually and collectively; they form coalitions which make the Triple Helix of university-industry-government relationships a cooperative game. The rules of a game determine players, actions of players and utility of playing the game; however, cooperative games are characterised by a set of players, coalitions they may form and payoffs or utility. The relations between coalitions and payoffs or utility are called characteristic function.

\section{Rules of the Triple Helix game}

According to Mêgnigbêto (Mêgnigbêto 2017; 2018), the Triple Helix relationships is a three-person cooperative game with transferable utility. The players are the three Triple Helix actors: university $(u)$, industry $(i)$ and government $(g)$. The set of coalitions they may form is $P=\{\varnothing,\{u\},\{i\},\{g\},\{u, i\},\{u, g\},\{i, g\},\{u, i, g\}\}$. Let $v$ be the characteristic function of the game; it entrusts with each coalition its payoff, e.g. the number of papers it published or the corresponding percentage share. Let us consider Fig. 1 which represents the basic configuration of the Triple Helix in terms of the number of publications per sphere. For simplification purpose, we will write, for example, $u i$ instead of $\{u, i\}$ to designate the coalition formed by players $u$ and $i$. The characteristic function of the Triple Helix game is as follows (Mêgnigbêto 2017; 2018):

$$
\left\{\begin{array}{c}
v(\varnothing)=\mathbf{0} \\
v(\boldsymbol{u})=\boldsymbol{U} \\
\boldsymbol{v}(\boldsymbol{i})=\boldsymbol{I} \\
\boldsymbol{v}(\boldsymbol{g})=\boldsymbol{G} \\
\boldsymbol{v}(\boldsymbol{u} \boldsymbol{i})=\boldsymbol{U}+\boldsymbol{I}+\boldsymbol{U I} \\
\boldsymbol{v}(\boldsymbol{u g})=\boldsymbol{U}+\boldsymbol{G}+\boldsymbol{U} \boldsymbol{G} \\
\boldsymbol{v}(\boldsymbol{i g})=\boldsymbol{I}+\boldsymbol{G}+\boldsymbol{I} \boldsymbol{G} \\
\boldsymbol{v}(\boldsymbol{u} \boldsymbol{i g})=\boldsymbol{U}+\boldsymbol{I}+\boldsymbol{G}+\boldsymbol{U I}+\boldsymbol{U} \boldsymbol{G}+\boldsymbol{I} \boldsymbol{G}+\boldsymbol{U I G}
\end{array}\right.
$$

where $U, I$ and $G$ represent the number of papers university, industry and government published on their own respectively; UI, UG and IG represent the number of papers university and industry, university and government, industry and government co-authored respectively; and $U I G$ the number of papers the three actors co-authored. UI, UG and IG exclude UIG (Mêgnigbêto 2017; 2018). ${ }^{1}$ 


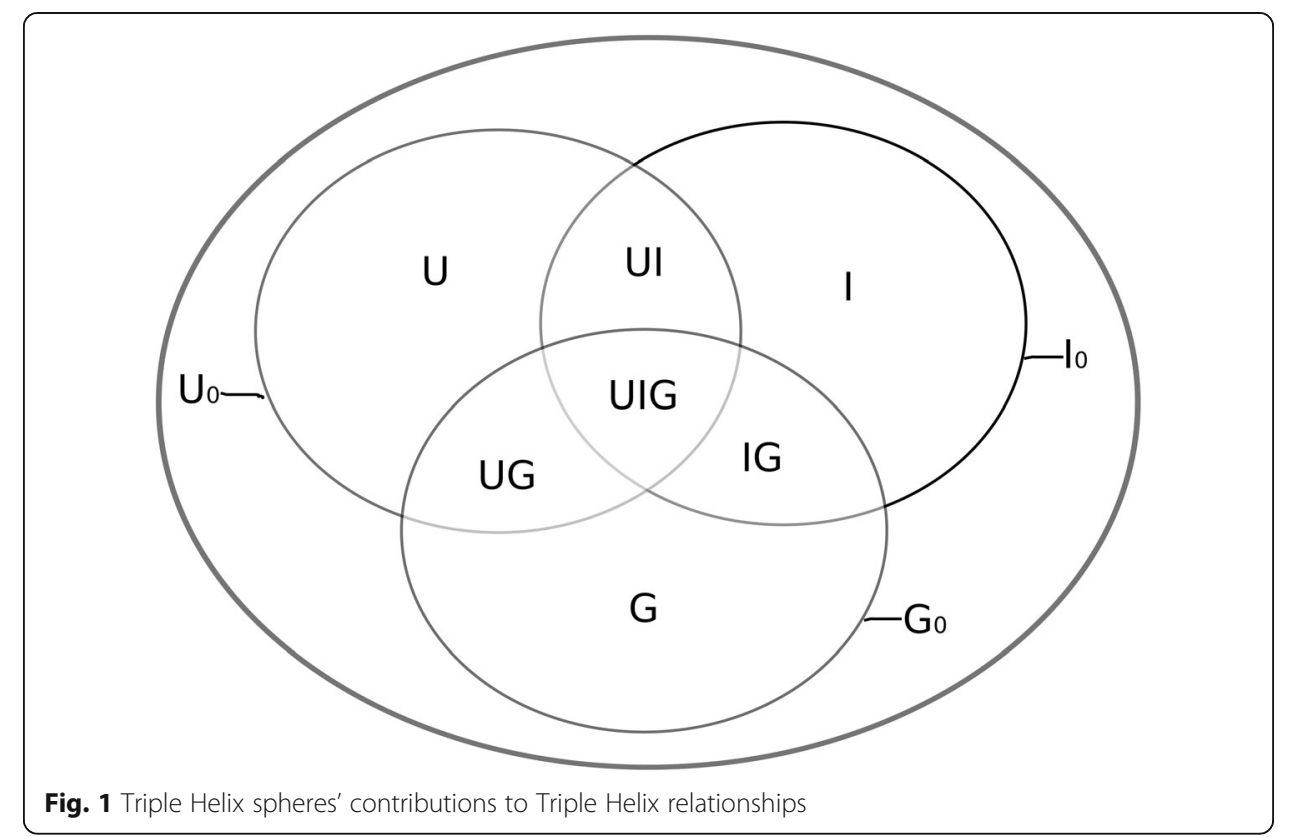

Core, Shapley value and nucleolus as indicators

The core of the Triple Helix game is determined by the number of publications each actor produced on its own (the lower bound) and the total number of publications that actor produced within the system, included in collaboration with other actors (the upper bound), under the condition that the three values add up to the total number of publications in the considered set. In its analytic form, the core of a Triple Helix cooperative game is the set of values $x_{\mathrm{u}}, x_{\mathrm{i}}$ and $x_{\mathrm{g}}$ of the utility of players $u, i$ and $g$ respectively, so that (Mêgnigbêto 2018):

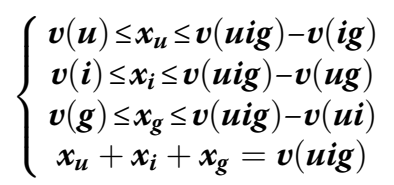

The core may be represented in a graphical form also. The core expresses actors' interests and constraints on these interests; it indicates the margin innovation actors have to bind agreements with the twofold target of creating synergy and redistributing benefits. The core determines existence and level of synergy within a Triple Helix innovation system (Mêgnigbêto 2018).

The Shapley value is the value an actor expects before the game begins or realises after the game ends (Roth 1988a, b). Within the framework of the Triple Helix relationships, Mêgnigbêto (Mêgnigbêto 2018) defined the Shapley value as the power of an actor to lead to and create synergy; it is the power an actor has to convince partners to collaborate with him or to form a coalition. Shapley $(1952,1953)$ gave a formula to compute this value. In the Triple Helix, the Shapley value is the triplet $S_{\mathrm{u}}, S_{\mathrm{i}}, S_{\mathrm{g}}$ for players university, industry and government respectively so that (Mêgnigbêto 2018): 


$$
\left\{\begin{array}{l}
S_{u}=\frac{2 v(u i g)+2 v(u)+v(u i)+v(u g)-2 v(i g)-v(i)-v(g)}{6} \\
S_{i}=\frac{2 v(u i g)+2 v(i)+v(u i)+v(i g)-2 v(u g)-v(u)-v(g)}{6} \\
S_{g}=\frac{2 v(u i g)+2 v(g)+v(i g)+v(u g)-2 v(u i)-v(i)-v(u)}{6}
\end{array}\right.
$$

The nucleolus measures excesses in the distributions of the total payoff in order to indicate the 'more acceptable' one by players (Schmeidler 1969; Kohlberg 1971). According to Mêgnigbêto (Mêgnigbêto 2018), in the framework of the Triple Helix relationships, the nucleolus is the effort of solidarity made by an actor (and its partners) to maintain synergy within the innovation system. The nucleolus has no analytic formula. It is hard to be computed (Sziklai 2015); indeed, it requires a step-by-step approach so that it is better to use an algorithm or software application for its computation. Sziklai (2015) established several methods on the computation of the nucleolus as well as the corresponding theory. Nowadays, there are many software applications that allow computing the nucleolus; even though using the same data, they always do not yield the same results. Guajardo and Jorusten (2015) revealed common mistakes in computing the nucleolus; Cano-Berlanga et al. (2017) claimed that the package 'Game theory' for the R statistical software (R Development Core Team 2017) takes into account these criticisms and produces robust results.

\section{Research data collection}

Leydesdorff (2003) analysed various world regions and countries while introducing the mutual information as an indicator of the synergy within the Triple Helix innovation system; he used data collected from the CD-ROM edition of the Science Citation Index 2000. Later on, Mêgnigbêto (2014a) used the same data for some of these countries, added those of South Korea harvested on the Web by Khan and Park (2011) and those of West Africa downloaded from Web of Science, to compute the transmission power. In order to avoid any bias linked to the sources of data or the level of data aggregation (country or region) on one hand, and to compare results with those of previous studies (e.g. Leydesdorff (2003) and Mêgnigbêto (2014a, 2016a)) on the other, we limited ourselves to countries common to the two studies; there are eight among which four developed namely USA, UK, Germany and France and four emerging namely Russia, India, Brazil and China.

\section{Data treatment}

Leydesdorff (2003) and Mêgnigbêto (2014a) presented data according to the Triple Helix spheres, e.g. innovation actors and their bi- or tri-lateral collaborations. We introduced these data in a spreadsheet for the computation of the characteristic functions according to the system 1 . Then, the upper and lower bounds to each actor's interests were determined to form the core. The 'ggtern' package (Hamilton 2016) for the $R$ statistical software ( $R$ Development Core Team 2017) were used to plot the lines determining the lower and upper bounds of the core on the ternary diagram. The diagram produced in a Scalable Vector Graphics (SVG) file (World Wide Web Consortium 2011) was edited with the Inkscape software application (Bah 2009; Inkscape Team 2017) to colour the surface 
area of the core. The Shapley value and the nucleolus were computed using the 'Game Theory' package (Cano-Berlanga et al. 2017) for the R statistical software.

\section{Results}

\section{Countries' total output and Triple Helix spheres' shares}

Among the selected countries, USA is the biggest science producer, far followed, in this order, by UK, Germany, France, Russia, China, India and Brazil at the rear. If the Brazilian output is considered as a unit of measurement, USA produced 26 units, UK 8, Germany 7, France 5, Russia and China each 2 and India 1. In five countries (USA, UK, Germany, Brazil and China), university is the biggest science producer, followed by government and industry, in this order; in the remaining three countries (France, Russia and India), government takes the first place, lagging university in the second position. Note that the governmental and academic productions are almost equal for France and India. The three bilateral collaborations university-industry, university-government and industry-government occurred in all countries, the tri-lateral too. Note that industry's percentage shares are very limited compared with those of other players; therefore, we plotted them separately in order not to bias visual analyses (Figs. 2 and 3 and Table 1).

\section{Characteristic functions}

Table 2 portrays the characteristic function of the Triple Helix game of the considered innovation systems. We use percentage shares instead of publication counts; therefore, the grand coalition has a utility of 100 always and then ignored in countries' comparison. In the five countries where university has the greatest percentage share (USA, UK, Germany, Brazil and China), the ranking of coalitions by decreasing payoffs puts ug in the first position followed by $u i, u, i g$, ig and $g$, confirming the findings of Mêgnigbêto (Mêgnigbêto 2018). In the remaining three countries where government is the first producer (France, Russia, India), coalitions $g$ is involved in come first followed by those $u$ is a member of, and finally the one-player coalition $i$; so the order is: $u g, i g, g, u i, u$ and $i$.

\section{Cores}

The analytic form of the core of the eight countries is presented in Table 3 and the graphical form in Figs. 4, 5, 6, 7, 8, 9, 10 and 11. For all the countries, the core borders the industry axis due to the low share of this actor to the scientific output; this finding confirms the results of Mêgnigbêto (2018) relative to the core of West Africa and South Korea. Particularly, the China core is closest to the industrial axis because this country's industrial output in the lowest one (cf. Table 2 or Table 3). Actors' contribution to the formation of the core-defined as the difference between the upper and the lower bounds of their interests as expressed in the analytic form of the core-is presented in Table 4. Note that the contribution of university and government determines the length of the core whereas that of industry determines its width. In the five countries with university as the biggest science producer, university contributes more to the formation of the core followed by government and then by industry; in the three countries where government is the biggest science producer, government contribution to the core 


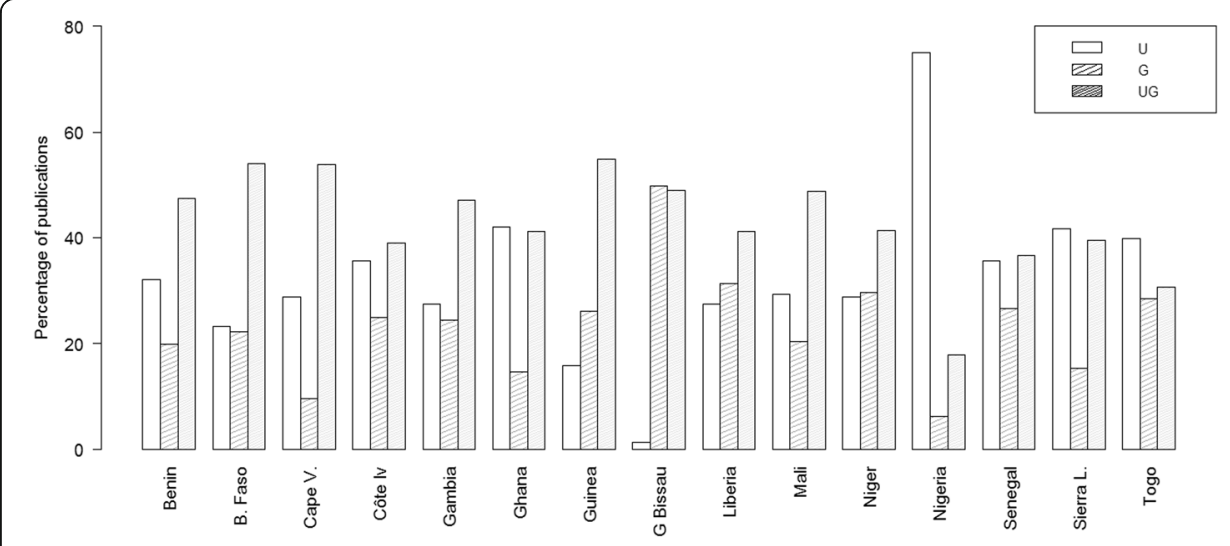

Fig. 2 Outputs of the Triple Helix spheres $(U, G, U G)$ in selected innovation systems

is highest in two (France and Russia) and university one is highest in one (India). In that latter group of countries, university and government have almost the same contribution, however. Industry's highest contribution to the formation of the core occurs in USA (5.01) and the lowest one in Russia. Consequently, the core of USA is the widest and that of Russia (1.65) is the thinnest.

\section{Shapley values and nucleoli}

The Shapley values and the nucleoli of the eight innovation systems are computed in Table 5. The Shapley value conserves the ranking of actors according to their output, e.g. where university is the biggest producer, it has the highest Shapley value followed by government and then by industry, and where government dominates the output, it has the highest Shapley value, followed by university and then by industry. That is not the case of the nucleolus: players are ranked in the same order whatever the country is and whatever the shares of actors are: university occupies the first position followed by government and then by industry. Even where government dominates the output, it loses its advantage to the benefit of

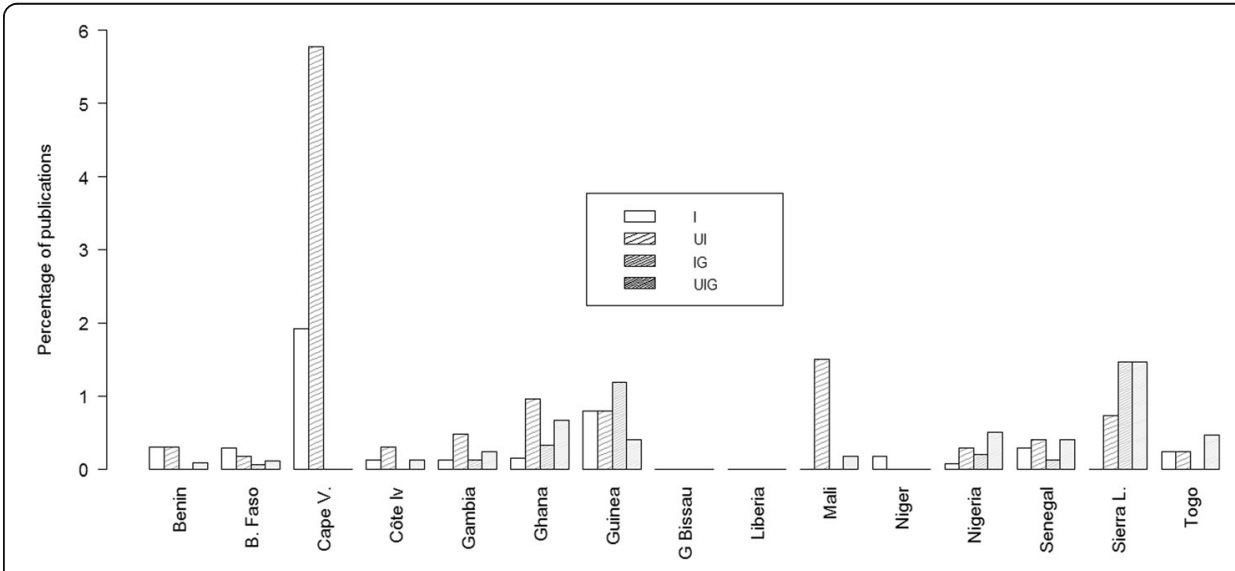

Fig. 3 Outputs of the Triple Helix spheres $(I ; U I ; G, U / G)$ in selected innovation systems 
Table 1 Outputs of the Triple Helix spheres in selected innovation systems

\begin{tabular}{llllllllll}
\hline Country & & $U$ & $I$ & $G$ & $U I$ & $U G$ & IG & UIG & Total \\
\hline USA & $\#$ & 152,449 & 6506 & 24,134 & 7200 & 37,834 & 1782 & 2666 & 232,571 \\
& $\%$ & 65.55 & 2.80 & 10.38 & 3.10 & 16.27 & 0.77 & 1.15 & 100 \\
UK & $\#$ & 39,316 & 1167 & 12,020 & 1719 & 13,098 & 394 & 690 & 68,404 \\
& $\%$ & 57.48 & 1.71 & 17.57 & 2.51 & 19.15 & 0.58 & 1.01 & 100 \\
Germany & $\#$ & 35,588 & 700 & 8627 & 1028 & 14,003 & 407 & 664 & 61,017 \\
& $\%$ & 58.32 & 1.15 & 14.14 & 1.68 & 22.95 & 0.67 & 1.09 & 100 \\
France & $\#$ & 13,571 & 507 & 14,020 & 439 & 11,593 & 452 & 530 & 41,112 \\
& $\%$ & 33.01 & 1.23 & 34.10 & 1.07 & 28.20 & 1.10 & 1.29 & 100 \\
Russia & $\#$ & 4978 & 102 & 10,996 & 76 & 6315 & 162 & 138 & 22,767 \\
& $\%$ & 21.86 & 0.45 & 48.30 & 0.33 & 27.74 & 0.71 & 0.61 & 100 \\
India & $\#$ & 4134 & 194 & 4563 & 97 & 1813 & 61 & 55 & 10,917 \\
& $\%$ & 37.87 & 1.78 & 41.80 & 0.89 & 16.61 & 0.56 & 0.50 & 100 \\
Brazil & $\#$ & 6052 & 46 & 1074 & 137 & 1727 & 32 & 52 & 9120 \\
& $\%$ & 66.36 & 0.50 & 11.78 & 1.50 & 18.94 & 0.35 & 0.57 & 100 \\
China & $\#$ & 13,235 & 61 & 3791 & 237 & 4610 & 68 & 114 & 22,116 \\
& $\%$ & 59.84 & 0.28 & 17.14 & 1.07 & 20.84 & 0.31 & 0.52 & 100 \\
\hline
\end{tabular}

university. Compared to the Shapley value, the nucleolus allocated to government less than it does to university and industry, whatever the country is.

\section{Discussion}

\section{Biggest Triple Helix producer leads to and creates synergy}

The eight Triple Helix games studied in this paper presented two patterns as regards the Triple Helix spheres' outputs. For the ones, university is the biggest science producer; for the others, government is the top science producer; as a result, industry is at the third place. Due to this change in the ranking of the Triple Helix actors by their output, the rank of coalitions according to their payoff also changes: coalitions that university is involved in are ranked first in countries where university is the top science producer, and coalitions government is a member of are ranked first in countries where government is the top science producer. This result prefigures the ranking of players by the Shapley value: university has the highest Shapley value in countries where it is the biggest science producer and

Table 2 Characteristic functions of the Triple Helix system of selected countries' Triple Helix game (values are in percentage)

\begin{tabular}{llllllll}
\hline Coalitions & $u$ & $i$ & $g$ & $u i$ & $u g$ & $i g$ & uig \\
\hline USA & 65.55 & 2.80 & 10.38 & 71.44 & 92.19 & 13.94 & 100 \\
UK & 57.48 & 1.71 & 17.57 & 61.70 & 94.20 & 19.85 & 100 \\
Germany & 58.32 & 1.15 & 14.14 & 61.16 & 95.41 & 15.95 & 100 \\
France & 33.01 & 1.23 & 34.10 & 35.31 & 95.31 & 36.43 & 100 \\
Russia & 21.86 & 0.45 & 48.30 & 22.65 & 97.90 & 49.46 & 100 \\
India & 37.87 & 1.78 & 41.80 & 40.53 & 96.27 & 44.13 & 100 \\
Brazil & 66.36 & 0.50 & 11.78 & 68.37 & 97.07 & 12.63 & 100 \\
China & 59.84 & 0.28 & 17.14 & 61.19 & 97.83 & 17.72 & 100 \\
\hline
\end{tabular}


Table 3 Analytic form of the core of the Triple Helix innovation systems of selected countries

\begin{tabular}{|c|c|c|c|c|}
\hline Country & USA & UK & Germany & France \\
\hline Core & $\left\{\begin{array}{c}65.55 \leq x_{u} \leq 86.06 \\
2.80 \leq x_{i} \leq 7.81 \\
10.38 \leq x_{g} \leq 28.56 \\
x_{u}+x_{i}+x_{g}=100\end{array}\right.$ & $\left\{\begin{array}{c}57.48 \leq x_{u} \leq 80.15 \\
1.71 \leq x_{i} \leq 5.80 \\
17.57 \leq x_{g} \leq 38.30 \\
x_{u}+x_{i}+x_{g}=100\end{array}\right.$ & $\left\{\begin{array}{c}58.32 \leq x_{u} \leq 84.05 \\
1.15 \leq x_{i} \leq 4.59 \\
14.14 \leq x_{g} \leq 38.84 \\
x_{u}+x_{i}+x_{g}=100\end{array}\right.$ & $\left\{\begin{array}{c}33.01 \leq x_{u} \leq 63.57 \\
1.23 \leq x_{i} \leq 4.69 \\
34.10 \leq x_{g} \leq 64.69 \\
x_{u}+x_{i}+x_{g}=100\end{array}\right.$ \\
\hline Country & Russia & India & Brazil & China \\
\hline Core & $\left(\begin{array}{c}21.86 \leq x_{u} \leq 50.54 \\
0.45 \leq x_{i} \leq 2.10 \\
48.30 \leq x_{g} \leq 77.35 \\
x_{u}+x_{i}+x_{g}=100\end{array}\right.$ & $\left\{\begin{array}{c}37.87 \leq x_{u} \leq 55.87 \\
1.78 \leq x_{i} \leq 3.73 \\
41.80 \leq x_{g} \leq 59.47 \\
x_{u}+x_{i}+x_{g}=100\end{array}\right.$ & $\left\{\begin{array}{c}66.36 \leq x_{u} \leq 87.37 \\
0.50 \leq x_{i} \leq 2.93 \\
11.78 \leq x_{g} \leq 31.63 \\
x_{u}+x_{i}+x_{g}=100\end{array}\right.$ & $\left\{\begin{array}{c}59.84 \leq x_{u} \leq 82.28 \\
0.28 \leq x_{i} \leq 2.17 \\
17.14 \leq x_{g} \leq 38.81 \\
x_{u}+x_{i}+x_{g}=100\end{array}\right.$ \\
\hline
\end{tabular}

government has the highest Shapley value in countries where it is the biggest science producer. The result confirms the one of Mêgnigbêto (Mêgnigbêto 2018) where university, the biggest science producer in South Korea and West Africa, has the highest Shapley value. Note that the production share and the Shapley value are linked; indeed, mathematically, the Shapley value is the expected utility of player (Roth 1988a); in other words, it is the average of utilities of an actor; consequently, the larger an actor's utility, the higher its Shapley value. In summary, the Triple Helix actor that has the largest share to publications has more strength to lead to and create synergy because it has more power to bind agreements and form coalitions.

\section{Government shows solidarity to maintain synergy}

Table 6 presents the difference between actors' Shapley value and nucleolus per innovation system. This quantity is positive for university and industry on one hand and negative for government on the other whatever the country is, meaning that the Shapley value for government is always greater than its nucleolus; conversely, university

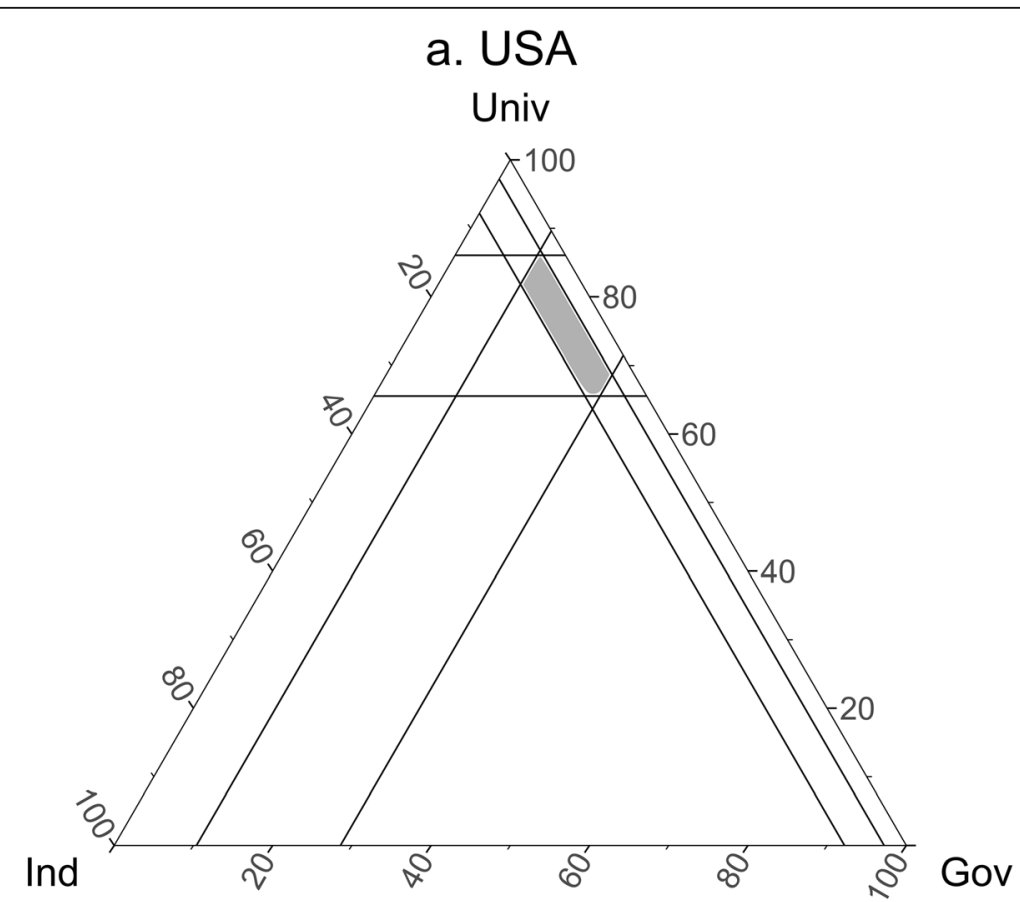

Fig. 4 Core of the USA Triple Helix game 


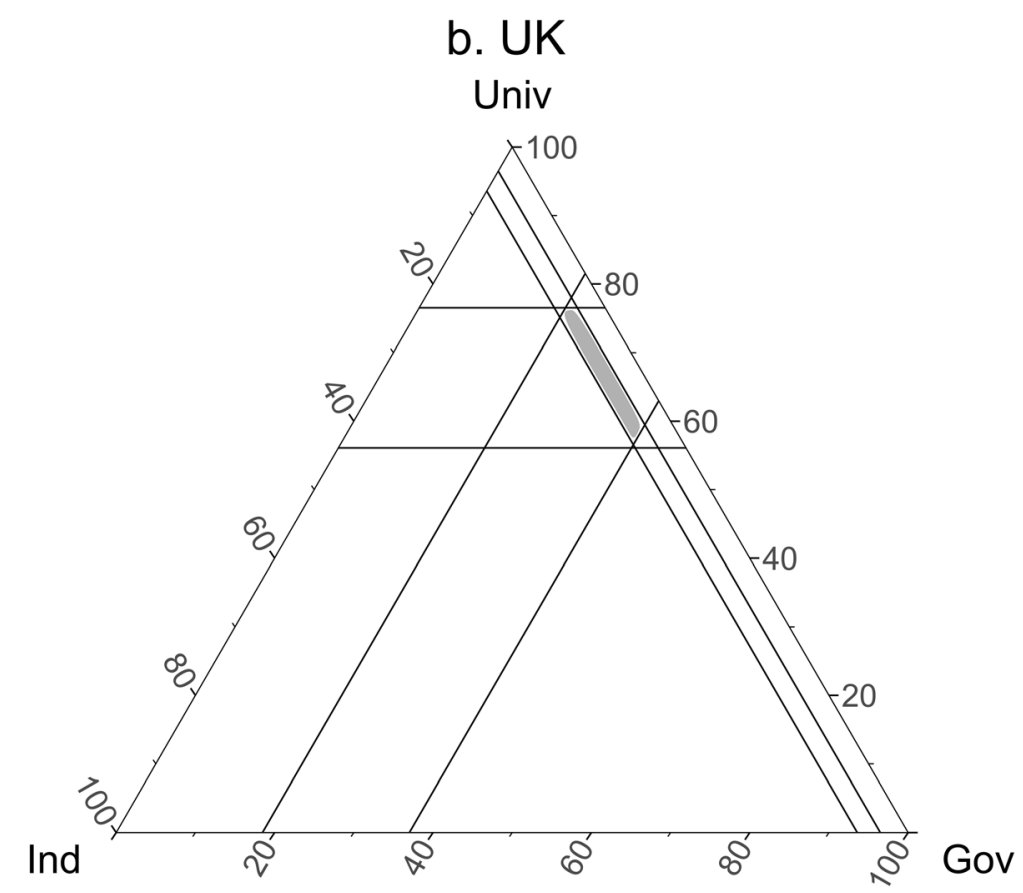

Fig. 5 Core of the UK Triple Helix game

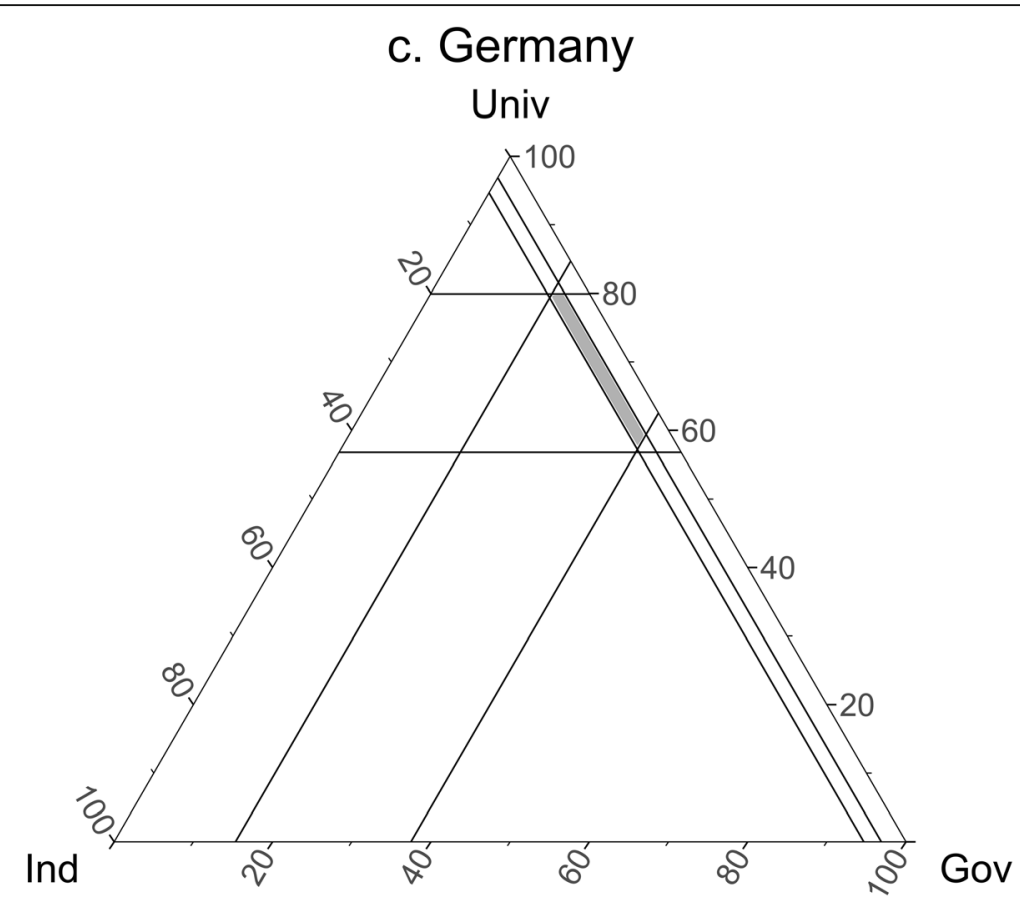

Fig. 6 Core of the Germany Triple Helix game 


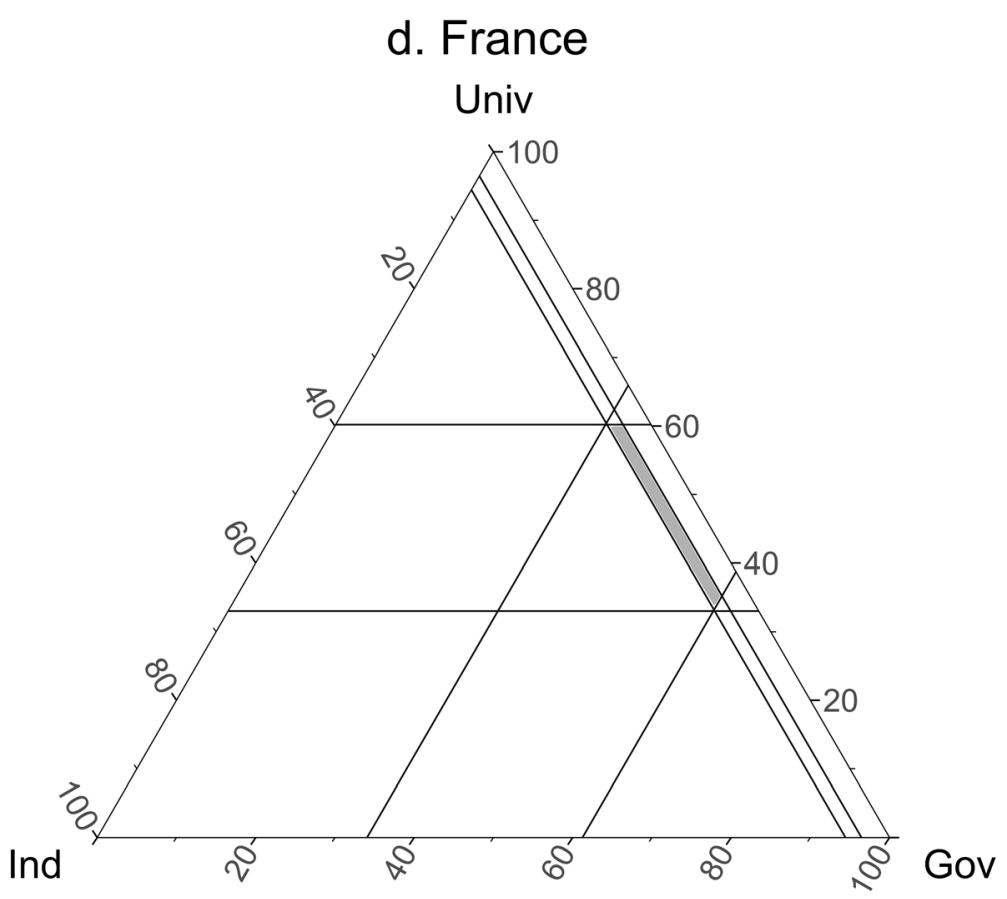

Fig. 7 Core of the France Triple Helix game

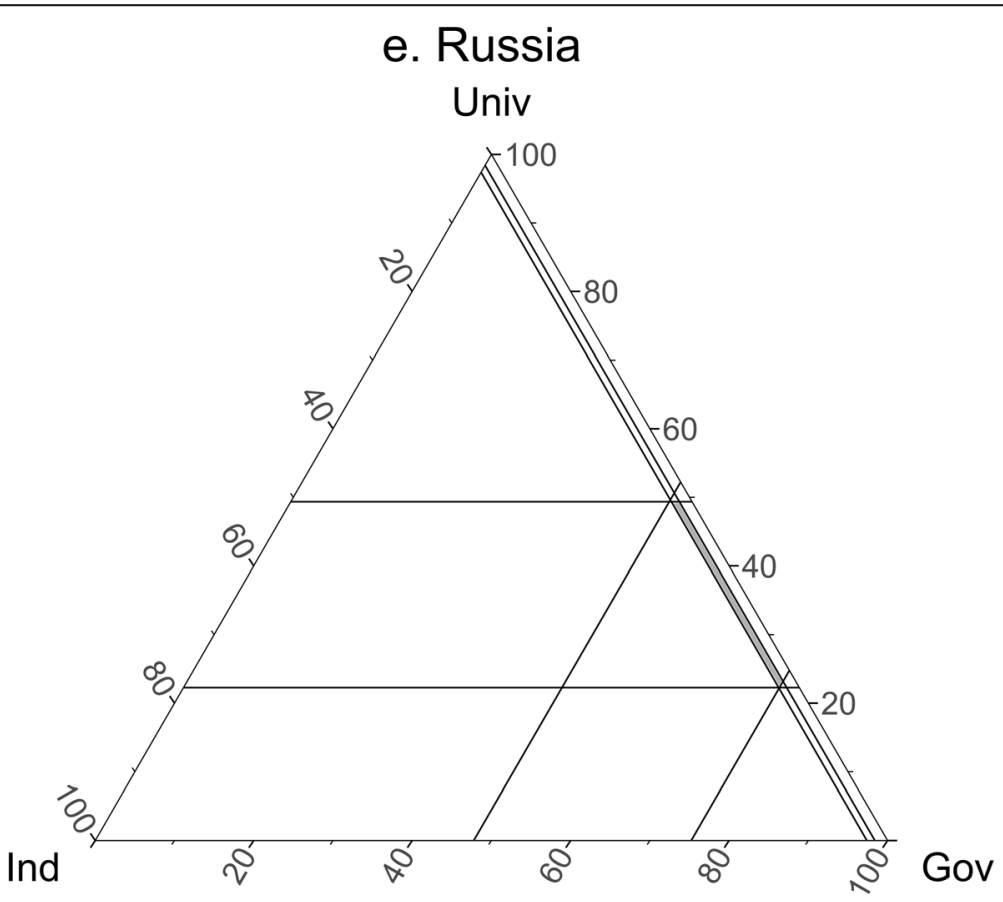

Fig. 8 Core of the Russia Triple Helix game 


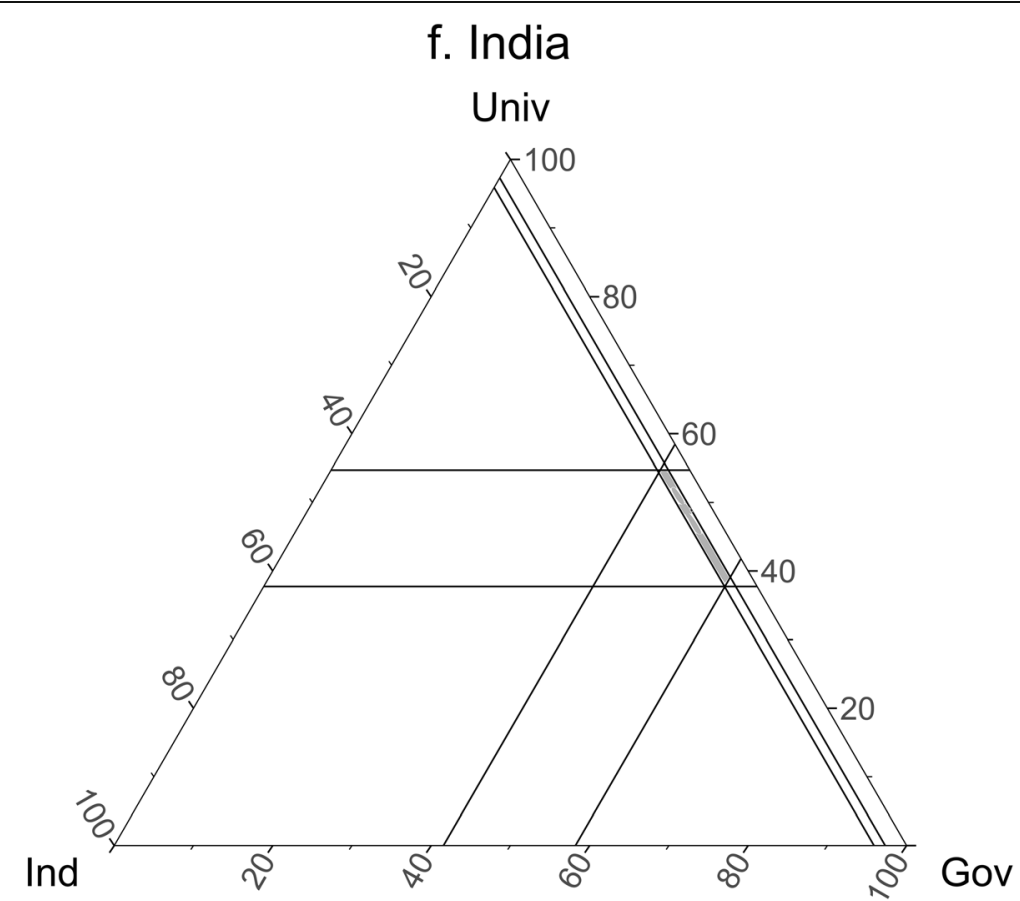

Fig. 9 Core of the India Triple Helix game

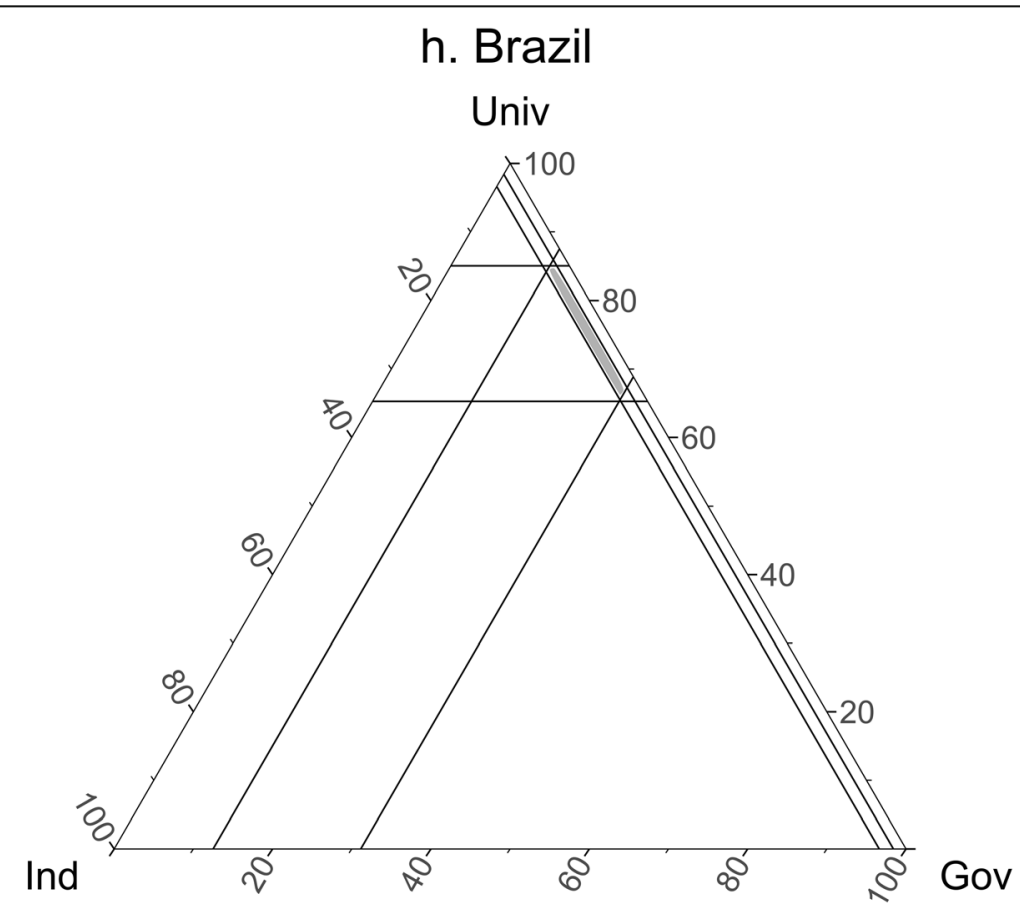

Fig. 10 Core of the Brazil Triple Helix game 


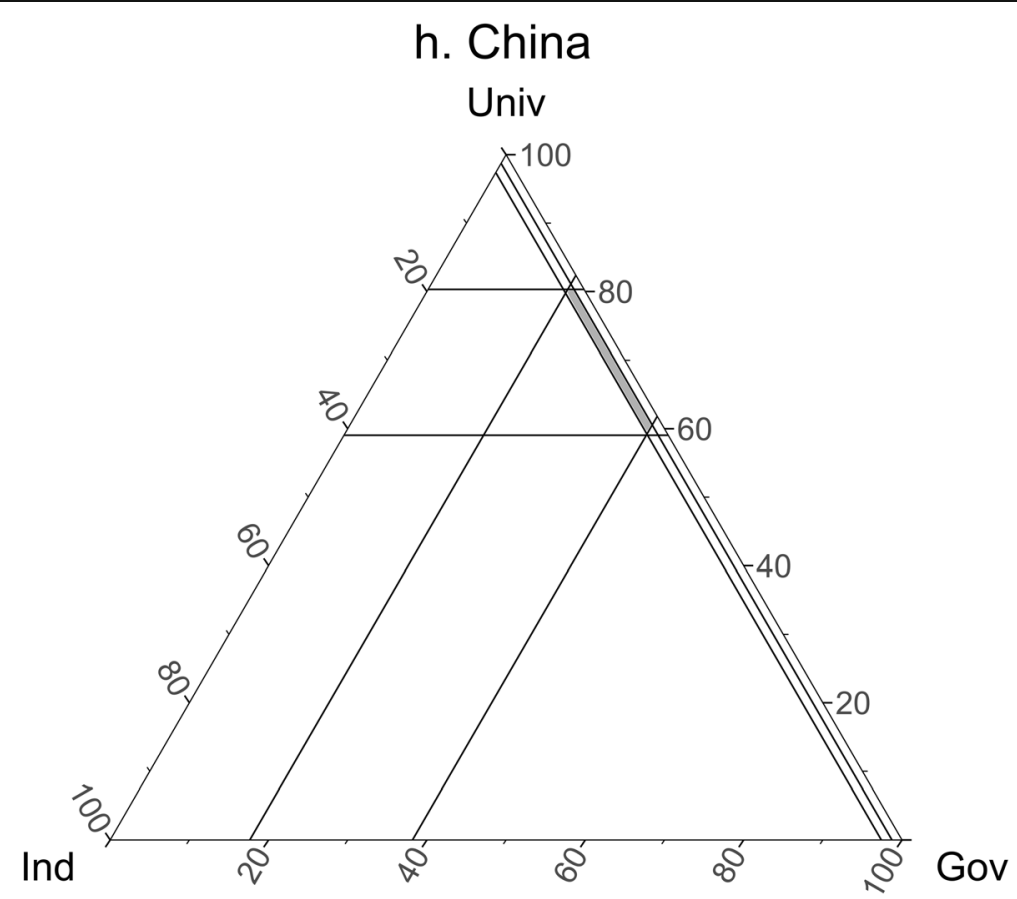

Fig. 11 Core of the China Triple Helix game

and industry Shapley value is lower than their nucleolus. In other words, in any innovation system, the nucleolus attributes to government less than it expects and to university and industry more than they do. Taking into account the quantity government loses, we can conclude that the nucleolus erodes government utility to the benefit of university mainly.

The nucleolus may be interpreted as a fair allocation based on the coalitions of which players are a member (Stolwijk 2010). It is more a way the total payoff can be distributed in a fair way over all the players based on all the coalitions of which he is a 'member' (Brackin 2002; Stolwijk 2010). An innovation actor with higher value of nucleolus does not necessary mean that the actor shows solidarity towards partners more than another actor. In fact, the nucleolus attributes value to players, but the meaning goes to coalitions that actors belongs to. To know the actors that show solidarity, one should compare the nucleolus to a particular distribution of the total payoff, the Shapley value in this case. If the nucleolus is lower than the Shapley value, it means that the actor accepts to make concessions by diminishing the payoff he expected (its Shapley value) to render coalitions payoffs fairer. Applying this logical reasoning to our case leads to the conclusion that government accepts to lose parts of its interest to allow the game to continue, else university and industry which have 'unfair' interests (according to the nucleolus) could leave the game. The quantity government loses by the

Table 4 Contribution to the formation of the core of selected Triple Helix games

\begin{tabular}{lllllllll}
\hline & USA & UK & Germany & France & Russia & India & Brazil & China \\
\hline University & 20.51 & 22.67 & 25.72 & 30.56 & 28.68 & 18.00 & 21.01 & 22.43 \\
Industry & 5.01 & 4.10 & 3.44 & 3.46 & 1.65 & 1.95 & 2.42 & 1.89 \\
Government & 18.18 & 20.73 & 24.70 & 30.59 & 29.06 & 17.67 & 19.86 & 21.67 \\
\hline
\end{tabular}


Table 5 Shapley values and nucleoli of selected Triple Helix games

\begin{tabular}{lllll}
\hline Player & & University & Industry & Government \\
\hline USA & Shapley value & 75.61 & 5.11 & 19.28 \\
UK & Nucleolus & 78.70 & 7.11 & 14.20 \\
& Shapley value & 68.64 & 3.59 & 27.77 \\
Germany & Nucleolus & 74.16 & 5.44 & 20.41 \\
& Shapley value & 71.00 & 2.69 & 26.31 \\
France & Nucleolus & 78.33 & 4.74 & 16.94 \\
& Shapley value & 48.07 & 2.75 & 49.18 \\
Russia & Nucleolus & 59.20 & 5.15 & 35.66 \\
& Shapley value & 36.10 & 1.17 & 62.72 \\
India & Nucleolus & 49.03 & 2.40 & 48.57 \\
& Shapley value & 46.78 & 2.67 & 50.55 \\
Brazil & Nucleolus & 53.85 & 3.65 & 42.50 \\
& Shapley value & 76.77 & 1.62 & 21.61 \\
China & Nucleolus & 83.58 & 2.76 & 13.66 \\
& Shapley value & 70.07 & 1.14 & 27.89 \\
\hline
\end{tabular}

nucleolus entirely goes to university in a large part and industry, so that in Table 6, the sum of the quantity in the cell with the heading university and the one in the cell with heading industry is equal to the value in the cell with the heading government in absolute value. The Shapley value for government is deemed unfair by the nucleolus that proceeds to corrections. Table 6 shows that the player government shows more solidarity, in absolute value, in Russia (13.13) than elsewhere, and less in the USA (5.98).

\section{Extent of synergy varies over countries}

Caplan and Sasaki (2006) provided a software application that analyses a cooperative game with transferable utility by (i) drawing the core, (ii) computing the Shapley value, (iii) computing the nucleolus and (iv) computing the percentage the surface area of the core occupies as regards the surface area of the ternary diagram. We used this application for the latter function. The surface of the core used as level of synergy within the eight innovation systems ranks France at the top with $2 \%$ followed by the USA (1.8\%), UK and Germany (1.7\% each), then, comes Brazil (1\%), Russia (0.9\%), China (0.8\%) and India (0.7\%). Clearly, this indicator operates a division of selected countries into two clusters according to the level of development: developed countries on one hand led by France including the USA, UK and Germany (with as score ranging from 1.7 to $2 \%$ ), and on the

Table 6 Difference between actors' Shapley value and nucleolus

\begin{tabular}{lllllllll}
\hline & Russia & France & Germany & China & Brazil & UK & India & USA \\
\hline University & 13.02 & 12.19 & 9.63 & 9.41 & 8.25 & 7.53 & 7.46 & 5.8 \\
Industry & 0.1 & 0.2 & 0.18 & 0.09 & 0.1 & 0.16 & 0.08 & 0.18 \\
Government & -13.13 & -12.39 & -9.8 & -9.5 & -8.34 & -7.68 & -7.54 & -5.98 \\
\hline
\end{tabular}

Note: Countries appear in decreasing order of absolute value of government losses 
other, emerging ones led by Brazil including Russia, China and India (with a score less than or equal to $1 \%$ each) (Fig. 12).

\section{State intervention policy determines the position of the core}

The examination of the positions of the cores on a ternary diagram reveals the existence of three clusters: (i) the first one where the core is located close to the university apex (at the top); this cluster groups together the five countries where university dominates the research system: USA, UK, Germany, Brazil and China; (ii) the second one where the core is located at the middle of the side of the triangle opposite to the industry apex; it groups two countries, France and India, where the shares of university and government are balanced; and (iii) the third one where the core is located almost close to the government apex; it is constituted of Russia only, where government dominates knowledge production. In our opinion, the three clusters illustrate the influence of political orientations on science, technology and innovation output.

In the Triple Helix theory, the term 'government' does not reduce to an executive institution but represents any public institution or power (Shinn 2002a, b). Therefore, it should be understood as state, i.e. consisting of three distinct sets of powers, each with its assigned role: (i) one is the legislature, whose role is to make the law; (ii) the second is the executive (sometimes referred to as 'the government'), which is responsible for implementing the law; and the third is the judiciary, which is responsible for interpreting and applying the law (World Bank 1997). Two concurrent modes of economic organisation of the state are governing the world: liberalism (or capitalism) and planned economy (also known under socialism and communism). Each has variants so that an economic organisation in one country is not the same in the other country. Liberalism supposes private ownership of production means where the state intervention in the economy is limited (Becker and Vasileva 2017), more limited in the USA than in Europe (World Bank 1997). In the USA, the state intervention in the economy is characterised by a laissez-faire, under the dictum 'That government is best that governs least' (World Bank 1996, 1997) whereas some Western European countries like Germany are characterised by a somewhat more 'social' market economy (World Bank 1996). That may explain the position of the core of the USA, UK and Germany Triple Helix game, three western countries where liberalism has been established for decades. Cacaly and Le Coadic (2007)

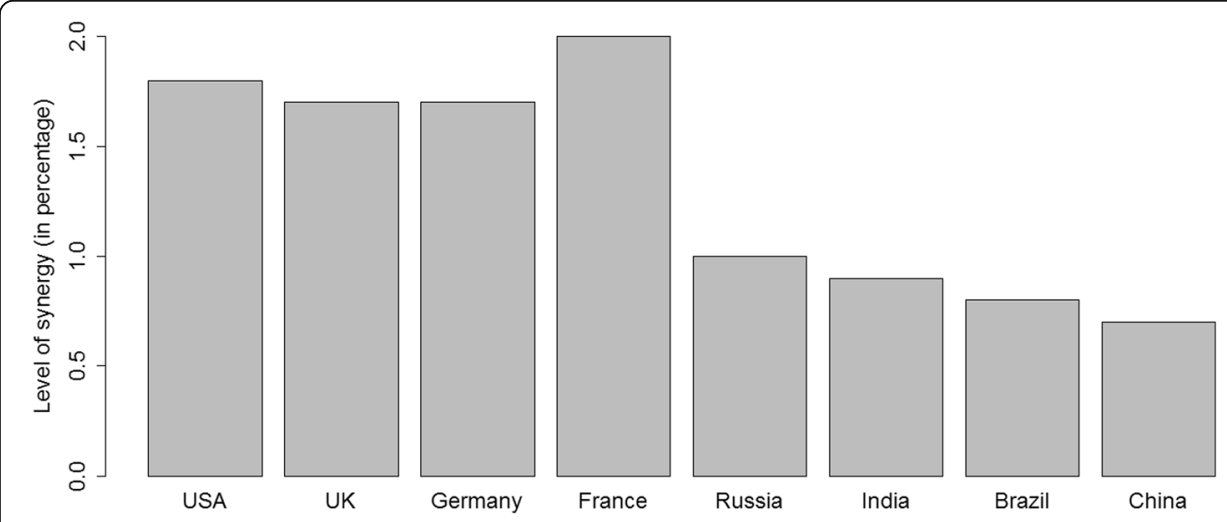

Fig. 12 Level of synergy within selected innovation systems 
described reforms, nationalisation and deregulation in France with the Left and Right influence on science, technology and innovation policy; this may explain the median position of the core of France Triple Helix game.

Brazil, Russia, India and China (BRIC) represent a rather homogenous group of countries as regards their economic organisation; they all have instituted planned economy-which means the state ownership in all economic sectors-and engaged reforms to liberalise in the 1980s (for Brazil) and the 1990s (for the three others) (World Bank 1997) to comply with the Western states' standards (Stivachtis 2015). Becker and Vasileva (2017) provided a comparison of their economic organisation over time: all of them are much less liberal than the Western countries and feature high levels of statism and similarly high levels of patrimonialism. They all started reforms. While Russia was the most liberal BRIC country in 1998, it de-liberalised so much that it became the second (after China) least liberal BRIC country in 2008. Brazil was the most liberal country in 2008, followed by India. Note that data analysed are related to papers published in 2000, a decade after the collapse of the Union of Socialist and Soviet Republics and the end of the Cold War following the advent of Perestroika (Gorbatchev 1987; Gorbachev 1989). Russia is still, then, a command-and-control economy, which explains the position of that country's Triple Helix game core.

\section{Comparison with mutual information and transmission power}

Table 7 presents the ranking of selected countries as regards the actors' Shapley value and nucleolus. It shows the rank of countries according to the power of actor in leading to and creating synergy within the Triple Helix innovation system. University has more power to lead to and create synergy in Brazil than elsewhere and less power in Russia. Industry has more power in the USA than elsewhere and less power in China; government has more power in Russia than elsewhere and less power in the USA. It is important to underline that university ranks first in the five countries where it is the biggest science producer before the three others; countries where government is the biggest producer are ranked first before the others. Industry Shapely value divides countries in two categories: the developed ones first and the emerging ones after. The rankings of countries by the Shapley value of the player industry results in the same order as the ranking of the countries by the transmission power (Mêgnigbêto 2014a): the developed one led by the USA and the emerging ones led by India. Because the value of the nucleolus could not be interpreted alone, we do not deem necessary to rank countries according to the nucleolus of actors.

\section{Conclusion}

Innovation system of eight countries was studied within the framework of the Triple Helix of university-industry-government relationships using game theory techniques

Table 7 Ranking of selected countries by the Shapley value

\begin{tabular}{lllllllll}
\hline Rank & 1 & 2 & 3 & 4 & 5 & 6 & 7 & 8 \\
\hline Shapley value $u$ & Brazil & USA & China & Germany & UK & France & India & Russia \\
Shapley value $i$ & USA & UK & France & Germany & India & Brazil & Russia & China \\
Shapley value $g$ & Russia & India & France & UK & China & Germany & Brazil & USA \\
\hline
\end{tabular}


and methods. The core, the Shapley value and the nucleolus were used as indicators to measure the synergy within an innovation system. The eight countries group together four developed ones (USA, UK, Germany and France) and four emerging (Russia, India, Brazil and China). Publication is used as a unit of analysis and data collected from Web of Science were analysed. University has the largest share of publications in five countries (USA, UK, Germany, Brazil and China) and government in three countries (France, Russia and India). Government showed solidarity towards other actors to maintain the synergy. The level of effort made varies, however, from one country to another, placing Russia at the top and USA at the rear. University and government have more power to lead to and create synergy in countries where each dominates the output; however, everywhere government shows solidarity towards other actors to maintain the synergy.

The position of the core on a ternary diagram distinguished three clusters: (i) the one where university dominates the output locating the core close to the university apex (USA, Brazil, UK, Germany, China); (ii) the second where the shares of university and government are balanced and the core is at a mid-way between the university and government apexes (France, India); and the third where government dominates the output and the core is located near the government apex (Russia). These three situations illustrate the state intervention policy in the economy.

The level of synergy operates a division of countries according to the level of development; the developed ones led by France (1.7-2\%) on one hand, and the emerging ones led by Brazil (less than or equal to 1\%) on the other. The performance of the selected countries has no relation with the mutual information; however, the ranking of countries by the Shapley value of industry results in the same as the ranking by the transmission power found in previous studies. The conclusions of this study illustrate that the state policy has influence on the relations between innovation actors. The paper innovates by borrowing techniques and tools from game theory to help in having new enlightenment on the study of the Triple Helix relationships.

\section{Endnotes}

${ }^{1}$ To obtain the characteristic function in percentage, one should multiply by 100 the right term of each equation and divide the result by the total number of papers within the system given by $v(u i g)=U+I+G+U I+U G+I G+U I G$ (see Mêgnigbêto 2018).

\section{Additional file}

Additional file 1: Translation of the abstract into Arabic. (PDF $53 \mathrm{~kb}$ )

Abbreviations

BRIC: Brazil, Russia, India and China; OECD: Organisation for Economic Co-operation and Development

Authors' contributions

The author read and approved the final manuscript.

Competing interests

The author declares that he has no competing interests. 
Received: 24 January 2018 Accepted: 29 July 2018

Published online: 17 September 2018

\section{References}

Bah T (2009) Inkscape: guide to a vector drawing program (Digital short cut). Pearson education, London

Becker U, Vasileva A (2017) Russia's political economy re-conceptualized: a changing hybrid of liberalism, statism and patrimonialism. J Eurasian Stud 8:83-96. https://doi.org/10.1016/j.euras.2016.11.003

Brackin RN (2002) N-person cooperative game theory solutions, coalitions, and applications. Master Thesis, University of Tennessee, Knoxville

Cacaly S, Le Coadic Y-F (2007) Fifty years of scientific and technical information policy in France (1955-2005). J Inf Sci 33:377384. https://doi.org/10.1177/0165551506075335

Cano-Berlanga S, Giménez-Gómez J-M, Vilella C (2017) Enjoying cooperative games: the R package GameTheory. Appl Math Comput 305:381-393. https://doi.org/10.1016/j.amc.2017.02.010

Caplan AJ, Sasaki Y (2006) Interactive geometry for surplus sharing in cooperative games. J Econ Educ 37:382

Choi S, Yang JS, Park HW (2015) The triple helix and international collaboration in science. J Assoc Inf Sci Technol 66:201-212

Ekaterina C (2012) University-industry-government interactions in Russian innovation policy. Master Thesis, University of Tempere, Tempere

Etzkowitz H, Leydesdorff L (1995) The Triple Helix---university-industry-government relations: a laboratory for knowledgebased economic development. EEASST Rev 14:14-19

Etzkowitz H, Leydesdorff L (2000) The dynamics of innovation: from National Systems and "Mode 2" to a Triple Helix of university-industry-government relations. Res Policy 29:109-123

Etzkowitz H, Webster A, Gebhardt C, Cantisano Terra BR (2000) The future of the university and the university of the future: evolution of ivory tower to entrepreneurial paradigm. Res Policy 29:313-330

European Commission (2010) European innovation scoreboard. Office for Official Publications of the European Communities, Luxembourg

European Commission (2014) Innovation union scoreboard. Office for Official Publications of the European Communities, Luxembourg

François C (2004) Synergy. International encyclopaedia of systems and cybernetics 741

Godin B (2005) The linear model of innovation: the historical construction of an analytical framework. Institut National de la Recherche Scientifique, Montréal

Godin B (2006) The linear model of innovation: the historical construction of an analytical framework. Sci Technol Hum Values 31:639-667

Godin B (2014) Invention, diffusion and linear models of innovation: the contribution of anthropology to a conceptual framework. J Innov Econ Manag 3:11-37. https://doi.org/10.3917/jie.015.0011

Gorbachev M (1989) Perestroika: new thinking for our country and the world. Nav War Coll Rev 42:151-153

Gorbatchev MS (1987) Perestroïka: vues neuves sur notre pays et le monde. Flammarion, Paris

Guajardo M, Jorusten K (2015) Common mistakes in computing the nucleolus. Eur J Oper Res 241:931-935

Hamilton N (2016) Package'ggtern: an extension to "ggplot2", for the creation of ternary diagrams

Inkscape Team (2017) Inkscape: draw freely

Ivanova IA, Strand $\varnothing$, Leydesdorff L (2014) Synergy cycles in the Norwegian innovation system: the relation between synergy and cycle values. Available SSRN 2492456

Katz JS (2006) Indicators for complex innovation systems. Res Policy 35:893-909

Katz JS (2016) What is a complex innovation system? PLoS One 11. https://doi.org/10.1371/journal.pone.0156150

Khan FG, Park HW (2011) Measuring the Triple Helix on the Web: longitudinal trends in the university-industry-government relationship in Korea. J Am Soc Inf Sci 62:2443-2455

Kohlberg E (1971) On the nucleolus of a characteristic function game. SIAM J Appl Math 20:62-65. https://doi.org/10.1137/0117107

Krippendorff K (2009a) Ross Ashby's information theory: a bit of history, some solutions to problems, and what we face today. Int J Gen Syst 38:189-212

Krippendorff K (2009b) Information of interactions in complex systems. Int J Gen Syst 38:669-680

Kwon K-S (2011) The co-evolution of universities' academic research and knowledge-transfer activities: the case of South Korea. Sci Public Policy 38:493-503

Kwon K-S, Park HW, So M, Leydesdorff L (2012) Has globalization strengthened South Korea's national research system? National and international dynamics of the Triple Helix of scientific co-authorship relationships in South Korea. Scientometrics 90:163-176

Leydesdorff $L$ (2003) The mutual information of university-industry-government relations: an indicator of the Triple Helix dynamics. Scientometrics 58:445-467

Leydesdorff L (2012) The Triple Helix, Quadruple Helix, ..., and an N-tuple of Helices: explanatory models for analyzing the knowledge-based economy? J Knowl Econ 3:25-35

Leydesdorff L, Etzkowitz H (1996) Emergence of a Triple Helix of university-industry-government relations. Sci Public Policy 23:279-286

Leydesdorff L, Etzkowitz H (2001) The transformation of university-industry-government relations. Electron J Sociol 5. http:// www.sociology.org/content/vol005.004/th.html

Leydesdorff L, Park H (2014) Can synergy in Triple Helix relations be quantified? A review of the development of the Triple Helix indicator. Triple Helix J Univ-Ind-Gov Innov Entrep 1:1-18. https://doi.org/10.1186/s40604-014-0004-z

Leydesdorff L, Perevodchikov E, Uvarov A (2015) Measuring triple-helix synergy in the Russian innovation systems at regional, provincial, and national levels. J Assoc Inf Sci Technol 66:1229-1238. https://doi.org/10.1002/asi.23258

Leydesdorff L, Sun Y (2009) National and international dimensions of the Triple Helix in Japan: university-industrygovernment versus international co-authorship relations. J Am Soc Inf Sci 60:778-788

Leydesdorff L, Zhou P (2013) Measuring the knowledge-based economy of China in terms of synergy among technological, organizational, and geographic attributes of firms. Scientometrics 98:1703-1719

Mêgnigbêto E (2013) Triple Helix of university-industry-government relationships in West Africa. J Scientometr Res 2:54-62. https://doi.org/10.4103/2320-0057.135413 
Mêgnigbêto E (2014a) Efficiency, unused capacity and transmission power as indicators of the Triple Helix of universityindustry-government relationships. J Inf Secur 8:284-294. https://doi.org/10.1016/j.joi.2013.12.009

Mêgnigbêto E (2014b) Information flow between west African Triple Helix actors. ISSI Newsl 10:14-20

Mêgnigbêto E (2014c) Information flow within West African innovation systems. Triple Helix J Univ-Ind-Gov Innov Entrep 1:113. https://doi.org/10.1186/s40604-014-0005-y

Mêgnigbêto E (2015a) Profiles of six OECD countries with regard to mutual information and transmission power. ISSI Newsl 11:16-23

Mêgnigbêto E (2015b) Effect of international collaboration on knowledge flow within an innovation system: a Triple Helix approach. Triple Helix J Univ-Ind-Gov Innov Entrep 2. https://doi.org/10.1186/s40604-015-0027-0

Mêgnigbêto E (2015c) Evaluation de l'économie du savoir au niveau de la région ouest-africaine: une approche basée sur le modèle de la Triple Hélice. Université d'Abomey-Calavi, Abomey-Calavi

Mêgnigbêto E (2016a) Research and innovation in West Africa: an informetric analysis within the framework of the Triple Helix model. Doctoral dissertation, Universiteit Antwerpen, Antwerpen

Mêgnigbêto E (2016b) Correlation between transmission power and some indicators used to measure the knowledge-based economy: case of six OECD countries. J Knowl Econ. https://doi.org/10.1007/s13132-016-0408-2

Mêgnigbêto E (2017) Modelling the Triple Helix of relationships with game theory: the rules of the game. ISSI Newsl 13:48-55

Mêgnigbêto E (2018) Modelling Triple Helix of university-industry-overnment relationships with game theory: core, Shapley value and nucleolus as indicators of synergy within an innovation system. J Informetr. https:/doi.org/10.1016/j.joi.2018.09.005

Meyer M, Grant K, Morlacchi P, Weckowska D (2014) Triple Helix indicators as an emergent area of enquiry: a bibliometric perspective. Scientometrics 99:151-174. https://doi.org/10.1007/s11192-013-1103-8

OECD (2010) Measuring innovation: a new perspective. OECD, Paris

OECD (ed) (2015) Frascati manual: guidelines for collecting and reporting data on research and experimental development, 7th edn. OECD Publishing, Paris

OECD, EUROSTAT (2005) Oslo manual: guidelines for collecting and interpreting innovation data, 3rd edn. Organisation for Economic Co-operation and Development - Statistical Office of the European Communities, Paris

Park HW, Leydesdorff L (2010) Longitudinal trends in networks of university-industry-government relations in South Korea: the role of programmatic incentives. Res Policy 2009:640-649

R Development Core Team (2017) R: a language and environment for statistical computing. R Foundation for Statistical Computing, Vienna

Roth AE (1988a) Introduction to the Shapley value. In: Roth AE (ed) The Shapley value: essays in honor of Lloyd S. Shapley. Cambridge University Press, Cambridge, pp 1-27

Roth AE (1988b) The expected utility of playing a game. In: Roth AE (ed) The Shapley value: essays in honor of Lloyd S. Shapley. Cambridge University Press, Cambridge, pp 51-70

Schmeidler D (1969) The nucleolus of a characteristic function game. SIAM J Appl Math 17:1163-1170. https://doi.org/10. $1137 / 0117107$

Shannon CE (1948) A mathematical theory of communication. Bell Syst Tech J 27:379-423 and 623-656

Shapley LS (1952) A value for n-person games. Federal Scientific and technical Information, Santa Monica

Shapley LS (1953) A value for n-person games. In: Kuhn HW, Ticker AW (eds) Contributions to the theory of games, volume II. Princeton University Press, Princeton, NJ

Shin JC, Lee SJ, Kim Y (2012) Knowledge-based innovation and collaboration: a triple-helix approach in Saudi Arabia. Scientometrics 90:311-326. https://doi.org/10.1007/s11192-011-0518-3

Shinn T (2002a) The triple helix and new production of knowledge prepackaged thinking on science and technology. Soc Stud Sci 32:599-614. https://doi.org/10.1177/0306312702032004004

Shinn T (2002b) Nouvelle production du savoir et Triple Hélice: tendances du prêt-à-penser les sciences. Actes Rech En Sci Soc 141-142:21-30. https://doi.org/10.3406/arss.2002.2815

Stivachtis YA (2015) Liberal democracy, market economy, and international conduct as standards of 'civilization' in contemporary international society: the case of Russia's entry into the 'community of civilized states'. J Eurasian Stud 6: 130-142. https://doi.org/10.1016/j.euras.2015.04.001

Stolwijk A (2010) Solution concepts in cooperative game theory. Master Thesis, Universiteit Leiden, Mathematisch Instituut, Leiden

Sziklai B (2015) On the computation of the nucleolus of cooperative transferable utility games. Doctoral dissertation, Eötös Loránd University, Budapest

von Bertalanffy L (1973) Théorie générale des systèmes. Dunod, Paris

World Bank (1996) World development report 1996: from plan to market. Oxford University Press, New York

World Bank (1997) World development report: the state in a changing world. Oxford University Press, Oxford

World Wide Web Consortium (2011) Scalable Vector Graphics (SVG) 1.1: W3C recommendation

Ye YF, Yu SS, Leydesdorff L (2013) The Triple Helix of university-industry-government relations at the country level, and its dynamic evolution under the pressures of globalization. J Am Soc Inf Sci Technol 64:2317-2325 